\title{
Benign Ovarian Luteinized Thecoma
}

National Cancer Institute

\section{Source}

National Cancer Institute. Benign Ovarian Luteinized Thecoma. NCI Thesaurus. Code C6264.

A non-metastasizing thecoma of the ovary that is characterized by the presence of lutein cells. 